\title{
FLUORITE - A MARKETABLE MINERAL COMMODITY FROM THE CENTRAL REGION OF MEDIEVAL HUNGARY
}

\author{
ÁGNES RITOÓK
}

\author{
Hungarian National Museum \\ Múzeum krt. 14-16, H-1088 Budapest, Hungary \\ agnes.ritook@gmail.com
}

\begin{abstract}
Several types of mineral beads can be found among the $11^{\text {th }}-12^{\text {th }}$-century grave assemblages of the Carpathian Basin. This paper examines the distribution of fluorite beads representing one type in Central and Eastern Europe. The distribution patterns have enabled the identification of the source of the raw material and they also outline the period's main trade routes.

Keywords: East-Central Europe, $11^{\text {th }}-12^{\text {th }}$ centuries, fluorite, beads
\end{abstract}

The burials in the churchyard of the medieval county centre at Zalavár yielded a total of 74 greyish-white and light or dark purple multi-faceted beads made from a mineral substance (Fig. 1). According to Dr. Gábor Papp, director of the Department of Mineralogy and Petrology of the Hungarian Natural History Museum, these beads were made of fluorite. ${ }^{1}$

In his study on the beads from the Pusztaszentlászló cemetery, Béla Miklós Szőke discussed the chronological position and socio-economic contexts of the greyish, greenish or purplish faceted beads. Citing geologist Csaba Révész, he noted that the raw material of the beads was fluorite, which originated from the Velence Hills, ${ }^{2}$ a low mountain range located near Székesfehérvár, in the central region of the medieval Kingdom of Hungary known as the medium regni from the thirteenth century onward. ${ }^{3}$

Szőke's assertions were widely accepted in Hungarian archaeological scholarship during the past decades, this being one of the reasons for Željko Tomičić's claim that "particular attention has been accorded to the necklaces strung of perforated, faceted amethyst and fluorite beads in Hungarian medieval studies, which in Giesler's typological scheme represented Type 41 a." ${ }^{4}$

The two minerals, amethyst and fluorite, were associated by Tomičić. The two indeed appear as alternatives in Jochen Giesler's cited study published in 1982, since the latter used the previously published data in his analysis. However, he described the beads from the Halimba cemetery as having been made from fluorite. ${ }^{5}$ Gyula Török, who uncovered the Halimba cemetery, wrote of amethyst beads in his initial Hungarian report on the burial ground. ${ }^{6}$ However, before publishing the final monographic study on the site, he showed the new bead types appearing in the cemetery's final, third phase "described as being of amethyst in the archaeological literature owing to their purplish colour" to Dr. János Erdélyi, the geologist of the Department of Minerals of the Hungarian National Museum. The

\footnotetext{
${ }^{1}$ I would here like to thank Dr. Gábor Papp and Dr. Bálint Péterdi for their kind help while writing this study.

${ }^{2}$ SZŐKE-VÁNDOR 1987.

${ }^{3}$ For a recent discussion of the term Medium regni, cf BENKŐ 2015, with further literature.
}

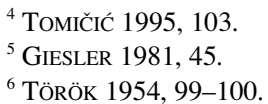


mineralogist cited as "Erdélyi CSc" in the final report declared that the beads had in fact been made from fluorite, ${ }^{7}$ the identification later quoted by Giesler, in stark contrast to Herbert Bach and Siegrid Dušek, whose oft-cited study first mentions the Halimba cemetery as yielding amethyst beads, ${ }^{8}$ even though there was not one single bead made from this mineral either among the finds from the latest phase, or the assemblages of the earlier phases.

Similar beads from the early Árpádian Age had first been described by Béla Pósta at the end of the nineteenth century. His excavation of the cemetery at Rákospalota yielded twenty-one "stone" beads from two burials as well as seven similar beads that could not be associated with any of the graves. Ágoston Franzenau, the then custodian of the Department of Minerals of the Hungarian National Museum, who happened to live in Rákospalota, "broadly identified them as fluorite beads". ${ }^{9}$ However, this identification was buried deep in Pósta's book, Régészeti tanulmányok Oroszföldön. II (Archäologische Studien auf russischem Boden. II) [Archaeological Studies in Russia] and in the entries of the 1892 Acquisitions register of the Hungarian National Museum, and thus escaped scholarly attention, ${ }^{10}$ given that the excavation itself remained unpublished until the appearance of Katalin I. Melis's study in $1997 .{ }^{11}$

The mineralogy of the beads must also be covered in this brief overview of previous research. Mineralogist Orsolya Kákay Szabó became interested in the beads of the Maroshegy cemetery in the wake of Kornél Bakay's studies on the burial grounds in the Székesfehérvár area. In her study published in 1974, she noted that archaeologists tended to identify the beads' material as amethyst based on their colour and she also drew attention to the grinding technique of the beads and the use of gimlets for drilling the perforations. However, these techniques could not be employed in the case of minerals with a similar hardness as amethyst, being only feasible for the much softer fluorite. The colour of the beads suggested a deposit in the Velence Hills, where raw material with a similar greenish-blue or purplish hue could be collected from surface outcrops. "It is noteworthy that the beads produced from fluorite occurring in the Velence Hills were highly sought-after because they can be found in grave assemblages across the entire county. Most archaeologists describe these finds as having been made from amethyst. It would be prudent have a mineralogist examine similar grave finds because this would shed light on the distribution range of the products of the 'workshop' active in the Székesfehérvár area. The bracelets and necklaces ground from fluorite of the Velence Hills are of outstanding significance because they represent the first known jewellery made from a mineral whose source lies in Hungary."12

Kákay-Szabó's assertions and research proposals remained buried in the 1974 Report of the Hungarian Institute of Geology and Geophysics, a publication that rarely reached archaeologists, particularly ones engaged in medieval studies.

Iván Mrázek’s book, Drahé kameny ve středověku Moravy a Slezska [Gemstones in medieval Moravia and Silesia], which also covers fluorite beads, appeared in 2000 as the second volume of a thematic series. The Moravian geologist discussed not only the finds from the regions indicated in the book's title (which include two fluorite beads from a single site in Bohemia), but also the similar finds brought to light in Poland and Slovakia. Citing the results of his own studies, he challenged the identification of the finds' material as amethyst, the usual case in the archaeological literature. His knowledge of the Hungarian sites is restricted to the data cited in Bach and Dušek's study. In his view, the appearance of the earliest pieces in Poland was followed by the spread of fluorite beads in Moravia and Slovakia after the final third of the tenth century, and the specimens from Hungary marked the southernmost boundary of the distribution. Examining the potential sources, he excluded the fluorite deposits known to him because the raw material from these was unsuitable for the manufacture of beads, but he also challenged a Scandinavian or Kievan origin because beads of this type are not attested there. "Ultimately, we can only assert that the origins of the early medieval fluorite beads remain shrouded in mystery. The source of the beads' raw material (and, by association, their production centre) should probably be sought beyond Central Europe."13

${ }^{7}$ TÖRÖK 1962, 104, note 45. J. Erdélyi's work on the beads is summarised by SzTRÓKAY 1978. Katalin Szilágyi devoted a separate study to the beads of the Hailmba cemetery. However, she did not discuss the second most frequent type, the beads made of minerals, which she only included in her statistical evaluation: SzILÁGYI 1994, 75. She repeated her views in a later study: SzILÁGYI 1995, 65, 67.

${ }^{8}$ BACH-DUŠEK 1971, 94, surprisingly citing the Germanlanguage publication.

${ }^{9}$ Pósta 1906, 352. Ágoston Franzenau was custodian of the Department of Minerals and Geology of the Hungarian National Museum from 1883 and its director from 1918 until his death in 1919.

${ }^{10}$ Inv. no. HNM 100/1892.1.-4., 5. -7., 26.-33., 112.-124.: ovoid fluorite beads with multiple or six facets.

${ }^{11}$ I. MELIS 1997, 41-47.

${ }^{12}$ KÁKAY Szabó 1974, 339-342.

${ }^{13}$ MrázeK 2000, 90. I am grateful to Dr. Balázs Komoróczy for kindly making this volume available to me. 
In the case of the fluorite beads found in Devín cemetery, Miloš Gregor et alii (2012) suppose that the raw material is probably of Bavarian origin. ${ }^{14}$ In 2013, Ewa Lisowska completed her doctoral thesis, Wydobycie i dystrybucja surowców kamiennych we wczesnym średniowieczu na Dolnym Ślasku [The mining and distribution of mineral raw material in Lower Silesia during the early Middle Ages], in which she sought to identify the origins of the raw material of the fluorite beads known from four sites in the study region. "Fluorite beads are one of the most rarely discussed find types. To the best of this author's knowledge, there are no studies in the foreign scholarly literature that raise or address issues concerning the processing and origins of this raw material. Only G. Rapp mentions fluorite beads from Predynastic Egypt." ${ }^{15}$ Based on Polish data, she suggested two possibilities, ${ }^{16}$ either that the raw material was imported from the Near or Far East through the mediation of the Kievan Rus, or, given the frequency of the finds, that the raw material had been mined locally in the Kaczawskie Mountains. However, she conceded that the latter option found little support either among archaeologists or gemmologists. ${ }^{17}$

My own research began with the purpose of updating the list of known sites based on the findings of research conducted during the decades after the publication of B. M. Szőke's monograph in 1987 and to refine, if necessary, the chronology and socio-economic contexts of these finds. ${ }^{18}$

\section{THE SELECTION OF THE SITES}

Initially, the most important issue was how to determine the beads' raw material, even if tentatively, based on the descriptions in the publications, according to which the beads shimmering in translucent greenish, greyish, pinkish, pale or dark purplish hues - although sometimes they faded when exposed to light - were all of the longish, multi-faceted barrel-shaped variety. The facets are blunt-edged, rounded and often barely visible. Several bead strands included broken pieces. (The abrasion of the facets and the beads' fragility can be attributed to the mineral's property, its low hardness.) The identifications appearing in the descriptions - amethyst/fluorite or, using a more careful wording, simply mineral raw material - and the accompanying illustrations indicated that fluorite beads have been attested in 79 cemeteries of the early Árpádian Age. Nevertheless, the list of sites can only be conclusively finalised following the mineralogical examination of the finds.

The 79 sites did not modify the chronological framework set up by B. M. Szőke: the beads first attested in the late tenth-century cemetery investigated at Sárbogárd attained their greatest popularity during the final third of the eleventh century, although their use can be noted up to mid-twelfth century in the burials of girls and younger women. ${ }^{19}$ (This broad chronology is valid not only for fluorite beads, but also for beads made from other minerals, and not solely in Hungary, but in the cemeteries uncovered in Moravia and Poland, too. ${ }^{20}$ ) New insights regarding the socio-economic contexts can be expected once the usage and distribution of beads made from rock crystal, carnelian and other minerals has been mapped, given that it was the mapping of the sites yielding fluorite beads that ultimately yielded new results.

\section{THE SITES}

The regional distribution of cemeteries yielding fluorite beads is uneven and this imbalance can no longer be explained by a differential research coverage or the lack of publications (see the Appendix).

The prominence of Transdanubia is obvious in terms of the number of sites and quantity of finds, followed by the regions north of the Danube, although the number of finds in the latter is much lower. Only a handful of

${ }^{14}$ GREGOR et al. 2012, 165.

${ }^{15}$ LISOWSKA 2013, 145

${ }^{16}$ LISOWSKA 2013, 225.

${ }^{17}$ LisowsKa 2013, 149.

${ }^{18}$ This research was inspired by an e-mail that I received at Christmas 2015. Dr. Jürgen Vollbrecht uncovered a grave containing fluorite beads in Bautzen and asked questions about them, which made me realize the need for detailed research on the topic.
${ }^{19} \mathrm{~A}$ later date has been proposed in two instances: Grave 96 at Zagreb-Stenjevec, containing ten basket earrings and two unperforated "ornaments", was assigned to the later twelfth century in view of the earrings: SimONI 2004, Kat. 22; Ószéplak/Krasno: the single fragmentary fluorite bead recovered from this site lay among the hand bones in Grave 538, dated by a coin of András II (1205-1235): KRUPICZA 1978, 232 and tab. XXXI.

${ }^{20}$ LISOWSKA 2013, 147, highlighting their dating value.

Acta Archaeologica Academiae Scientiarum Hungaricae 71, 2020 
cemeteries east of the Danube yielded fluorite beads. This uneven distribution provided important clues for the source of the beads' raw material, although it also called for an explanation for the imbalances in distribution.

\section{THE RAW MATERIAL SOURCE}

In Alexander Ruttkay's view, published in a study written in 1979, the source of the raw material used for the "amethyst" beads from the Ducó cemetery (Ducové-Moravany nad Váhom, SK), which still lacks a detailed publication, and from the other Slovakian burial grounds was Selmecbánya (Banska Štiavnica, SK) ${ }^{21}$ His claim was seemingly supported by the series of sites located north of the Danube and by the fact that Selmecbánya appears among the roughly twenty locations where fluorite deposits have been identified. ${ }^{22}$

The first mention of the mine in the written sources dates from 1226; however, Zoltán Batizi suggested that the denarii of King István I (997-1038) were minted in Esztergom-Kovácsi from silver mined at Selmecbánya. ${ }^{23}$ Yet, the fluorite beads known from sites north of the Danube could hardly have originated from this deposit since the fluorite crystals from Selm ecbánya are small, barely $1 \mathrm{~cm}$ large. ${ }^{24}$ (As a matter of fact, the countless gemstone beads from the Kovácsi cemetery excavated during the past years did not include a single specimen made of fluorite, as kindly mentioned by Edit Tari, the site's excavator.)

A suitable raw material could have been obtained from Gyöngyösoroszi, a village in northern Hungary, on the southern slope of the Mátra Mountains, given that the crystals in this deposit are considerably larger $(3 \mathrm{~cm})$. However, there are no burial grounds in the broader area whose finds included fluorite beads. Large crystals suitable for bead manufacture can be solely found in the Velence Hills. The distribution of archaeological sites likewise points to this region. There are no written sources on this deposit. The rediscovery of this fluorite deposit in 1951 reads like a grotesque fairy tale: one fine August day, while working on Mt. Üveghegy [Glass mountain] at Pákozd, "geologist Béla Jantsky [...] was almost blinded by the dazzling light reflected from a palm-sized cleavage surface in one of the rocks crushed by Soviet tanks that had previously partaken in a military exercise in the area." 25

\section{DISTRIBUTION OF SITES IN THE CARPATHIAN BASIN}

A closer look at the distribution of sites reveals certain concentrations even within one or another region (Figs 2-3). The cemeteries yielding a rich array of beads are located on the northern shoreline of Lake Balaton, along the "military road", a major artery of communication, whose existence and use is mentioned in the sources from the early Árpádian Age onward. The road turned slightly southward in the Lower Zala Valley, probably in the Zalavár area. The southernmost point in the bead finds strung out along the road is marked by Grave 96 of the ZagrebStenjevec cemetery, used in the eleventh-thirteenth centuries. In addition to ten basket earrings, this burial yielded a dark purple and a translucent "ornament", the former described as a polygonal amethyst, the latter as a polygonal or barrel-shaped amethyst or rock crystal. ${ }^{26}$ In the case of fluorite beads, the Croatian terminology employs the term "amethyst and fluorite" ("ametist i fluorit"), but purplish pieces are consistently described as amethyst. ${ }^{27}$ Given this general usage, the uncertainties in the description prompted the tentative inclusion of these two beads among the ones made of fluorite.

From Székesfehérvár, the road led north-eastward to the Pest ferry. ${ }^{28}$ The "bead route" then ran along the Danube's northern bank north- and westward along the river's left bank tributaries, principally in the Nyitra /Nitra Valley. The concentration of sites around Nyitra (Nitra, SK) and in the city's broader area is particularly striking (even if the number of beads is low because the cemeteries have only been partially excavated). However, the by far the highest number of fluorite beads came to light not in this area, but along the Vág/Váh in the region lying

\footnotetext{
${ }^{21}$ Ruttkay, A. 1979, 22; for the central Slovakian mines in general, cf. Ruttkay, A. 1996, 407.

${ }^{22}$ Minerals 2002, 187-188. For the Hungarian deposits, cf. GEODA 23 (2013):3.

${ }^{23}$ BATIZI 2018, 168. Garamszentbenedek Abbey received the estate or village of Baka in 1075, where there was a separate land for the mine (terra Banensium) in 1156. Although silver mining is mentioned only in 1270, it could have been mined well before this date. I am grateful to B. F. Romhányi for the data.

${ }^{24}$ Minerals 2002, 188.

${ }^{25}$ PAPP 2018, 1559.

${ }^{26}$ SimONi 2004, Kat. 22.

${ }^{27}$ JERŠEK 2018, 29, 33, 34.

${ }^{28}$ GYÖRFFY 1987, 341. 

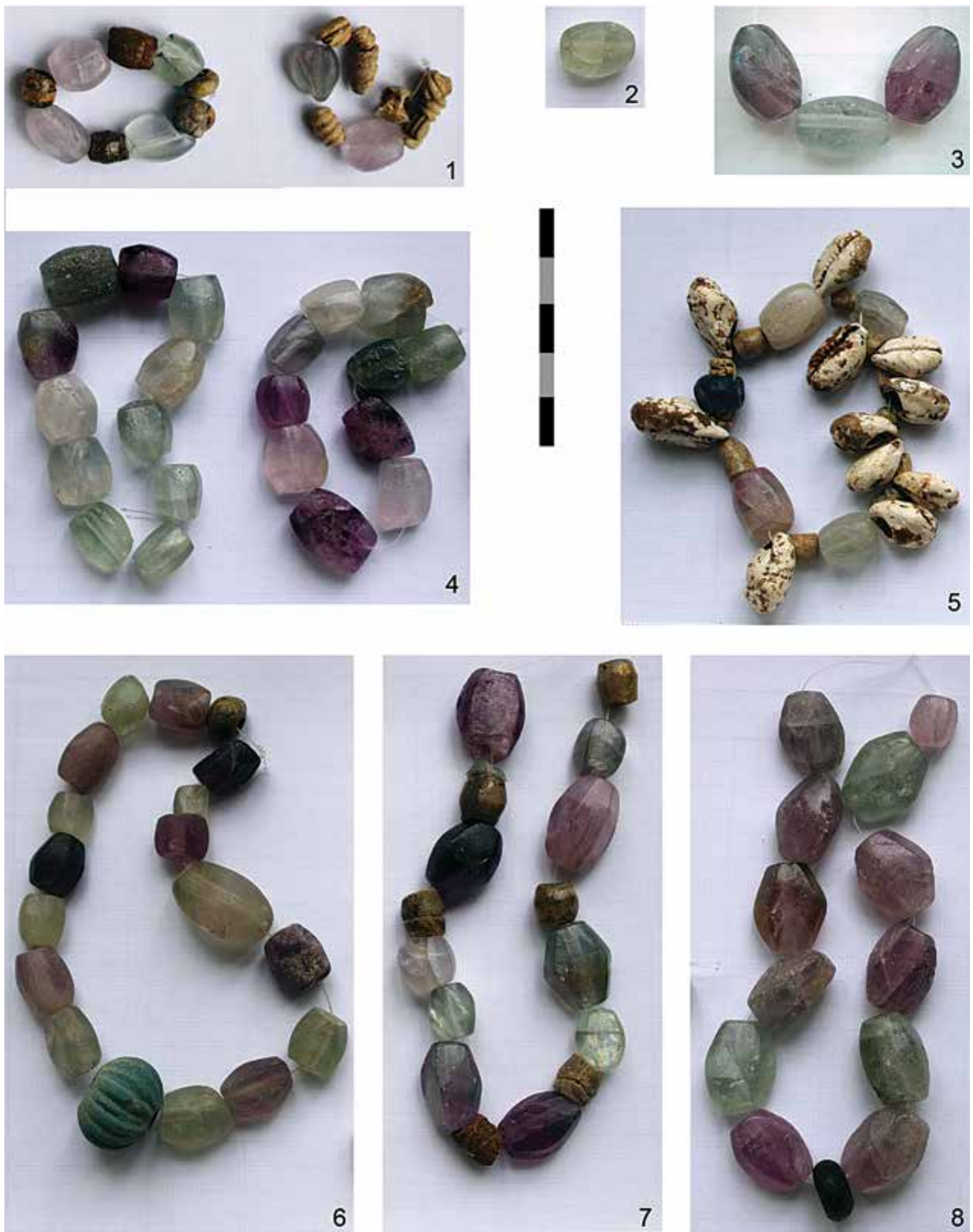

Fig. 1. Zalavár-Kápolna. Strands of fluorite beads from the graveyard around the church. 1: Grave 105/96; 2: Grave 37/51; 3: Grave 107/96; 4: Grave 145/96; 5: Grave 114/96; 6: Grave 86/1951; 7: Grave 60/96; 8: Grave 126/96 (photo: author) 


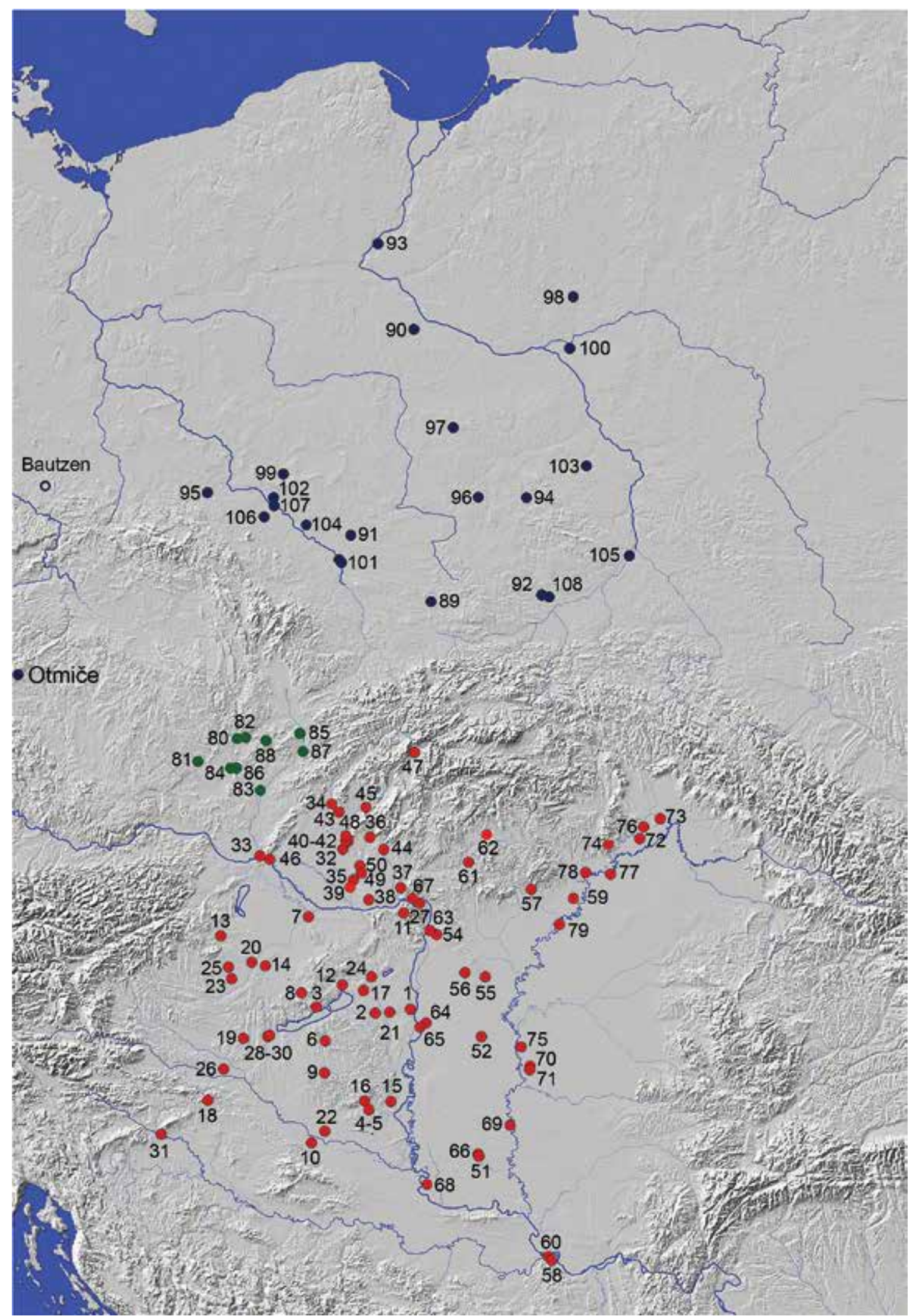

Fig. 2. Sites yielding fluorite beads (basic map: Balázs Holl) 


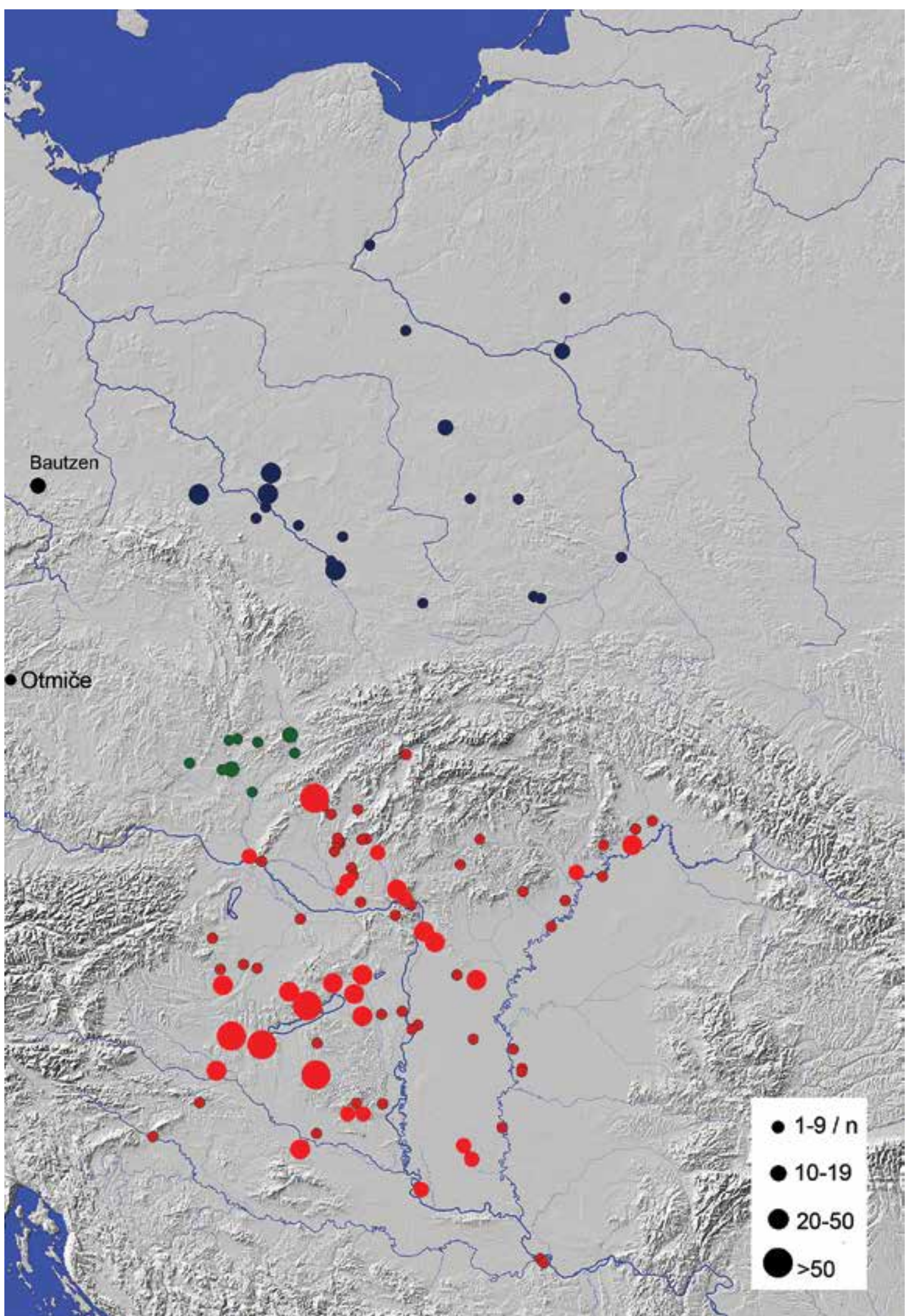

Fig. 3. Number of fluorite beads according to sites (basic map: Balázs Holl) 
north of the Danube, specifically in the Ducó cemetery lying in the "border zone". A tolling station (Banka) on the Vág/Váh is mentioned this area in $1270,{ }^{29}$ which, judging from the bead finds, had already been active in the eleventh-twelfth centuries, which can in all likelihood be associated with the relative proximity of the road leading to Brno through Holics (Holič, SK).

Looking at the region between the Transdanubian road and the right Danube bank, the lack of fluorite beads in the settlements lying in the northern third of Transdanubia is striking. The fluorite beads do not outline a route along the right Danube bank, confirming Károly Mesterházy's contention regarding the findspots of tenth-century imports for a broader time period too: "The major trade route was not the limes road along the right Danube bank, but the former military road along the northern bank." ${ }^{30}$

In all likelihood, the three fluorite beads known from Györ-Pósdomb reached that site along the water route of the Rába, while the exemplar from Kesztölc can be explained by the connections maintained with Garamszentbenedek Abbey $;^{31}$ seven fluorite beads have also been reported from Visegrád, from the cemetery uncovered in the area of the resort of the Hungarian National Bank.

A smaller concentration can be noted in County Vas; the westernmost occurrence at Középpulya (Mittelpullendorf, A) can be assigned to this group.

Similarly to the Ducó cemetery, the remarkably high number of beads in the Pusztaszentlászló burial ground (129 pieces in all) can be explained by the site's geopolitical location, even if the exact line of the road leading to Slavonia remains controversial. ${ }^{32}$

Flowing from Székesfehérvár into the Danube, the Sárvíz, which could be navigated before its regulation in the eighteenth century, probably acted as the communications route south towards Pécs. The sites at Sellye and Josipovo (HR) south-west of Pécs probably mark the location of the ferry across the Drava.

South of the Pest ferry, the next crossing-place across the Danube at Solt is indicated by the fluorite beads from the cemeteries at Solt-Tételhegy and Solt-Kalimajor. Further downstream, the beads from Vajska and two suburbs of Belgrade, Mirijevo and Karaburma, mark the series of finds along the Danube, which in all likelihood also reflect the location of ferries.

The sites east of the Danube can be divided into two typical groups. Early Árpádian Age cemeteries with fluorite beads have been uncovered near the ferries across the Tisza (predominantly along the river's upper reaches), ${ }^{33}$ a chain that extends into the Bodrogköz region (Karcsa, Szomotor, Lelesz). The other group of sites probably lay along or near the roads passing through the Danube-Tisza interfluve. The sites making up the two groups are not haphazard: the sites outline a route that coincides with the salt transportation routes recently mapped by Beatrix F. Romhányi $\mathrm{i}^{34}$ and provide a fine illustration of the use of the Tisza ferries already during the early Árpádian Age.

Salt was one of the most important commodities of inland trade from the very beginning ${ }^{35}$ and other commodities were also transported along the roads and waterways used in its trade. There can be no doubt that these roads played a prominent role in the far-ranging contacts of the settlements associated with the Transdanubian cemeteries yielding fluorite beads, either because the settlement lay along or in the immediate proximity of the transportation route, as Rábasömjén and Mesteri-Intapuszta, ${ }^{36}$ or because its occupants, or at least some of them, were active participants of the inland trade conducted along them. ${ }^{37}$ Whichever the case, this issue can only be resolved through the detailed study of the road network using both archival sources and the archaeological record as well as of the diachronic changes in geographic conditions since there were major shifts in this network in Transdanubia during the Árpádian Age ${ }^{38}$ Studies along these lines would incidentally also shed light on the intriguing issue of why some cemeteries with an abundance of fluorite beads were also remarkably rich in tin/lead ring jewellery.

On the testimony of the current archaeological record, the "treasure of the medium regni" did not reach the region beyond the Tisza and Transylvania, ${ }^{39}$ while, at the same time, the beads attest to intense contacts between

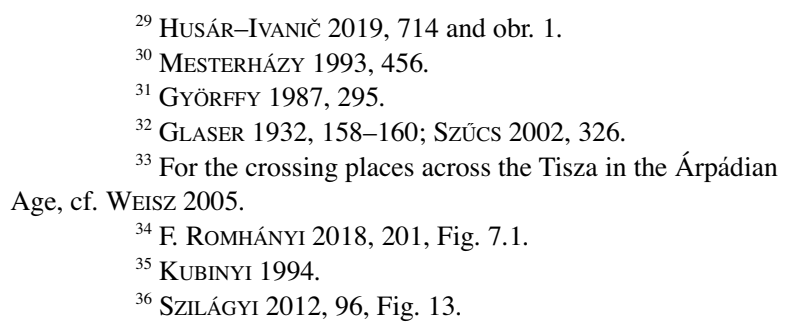

\footnotetext{
${ }^{37}$ It has been noted in several cases, for example at Visegrád and Kaposvár, that only one of two or more contemporaneous cemeteries lying close to each other contained fluorite beads.

${ }^{38}$ GLASER 1929.

${ }^{39}$ László Kovács interpreted the lack of fluortie beads (as well as of spherical carnelian and rock crystal beads and of square green glass beads) among the beads of the Magyarhomorog cemetery as one of the site's singular traits: KovÁcs 2019, 400.
} 
Transdanubia and the regions north of the Danube. K. Mesterházy's studies have furnished convincing proof that in exchange for the beads, Transdanubia and the regions north of the Danube received Byzantine and Balkanic commodities from the Tisza region. ${ }^{40}$

\section{BEYOND THE CARPATHIANS}

Fluorite beads have been reported from thirty-one sites in the region beyond the Carpathians (Figs 2-3): two beads from a cemetery in Bohemia (Otmiče), ${ }^{41}$ forty-eight beads from eight cemeteries in Moravia and possibly similar beads (whose number remains unknown) have been mentioned from another cemetery. ${ }^{42}$ These nine sites lie in the region's south-easterly area near the Hungarian border, in the foreland of the Holics ferry.

A substantial number of Hungarian coins were deposited in burials during the eleventh century, the latest of which were mostly minted by András I (1043-1060). Disregarding a few years in the first third of the eleventh century, minting in Moravia began in the $1060 \mathrm{~s} .{ }^{43}$ A comparison of the distribution of Hungarian coins and of fluo-

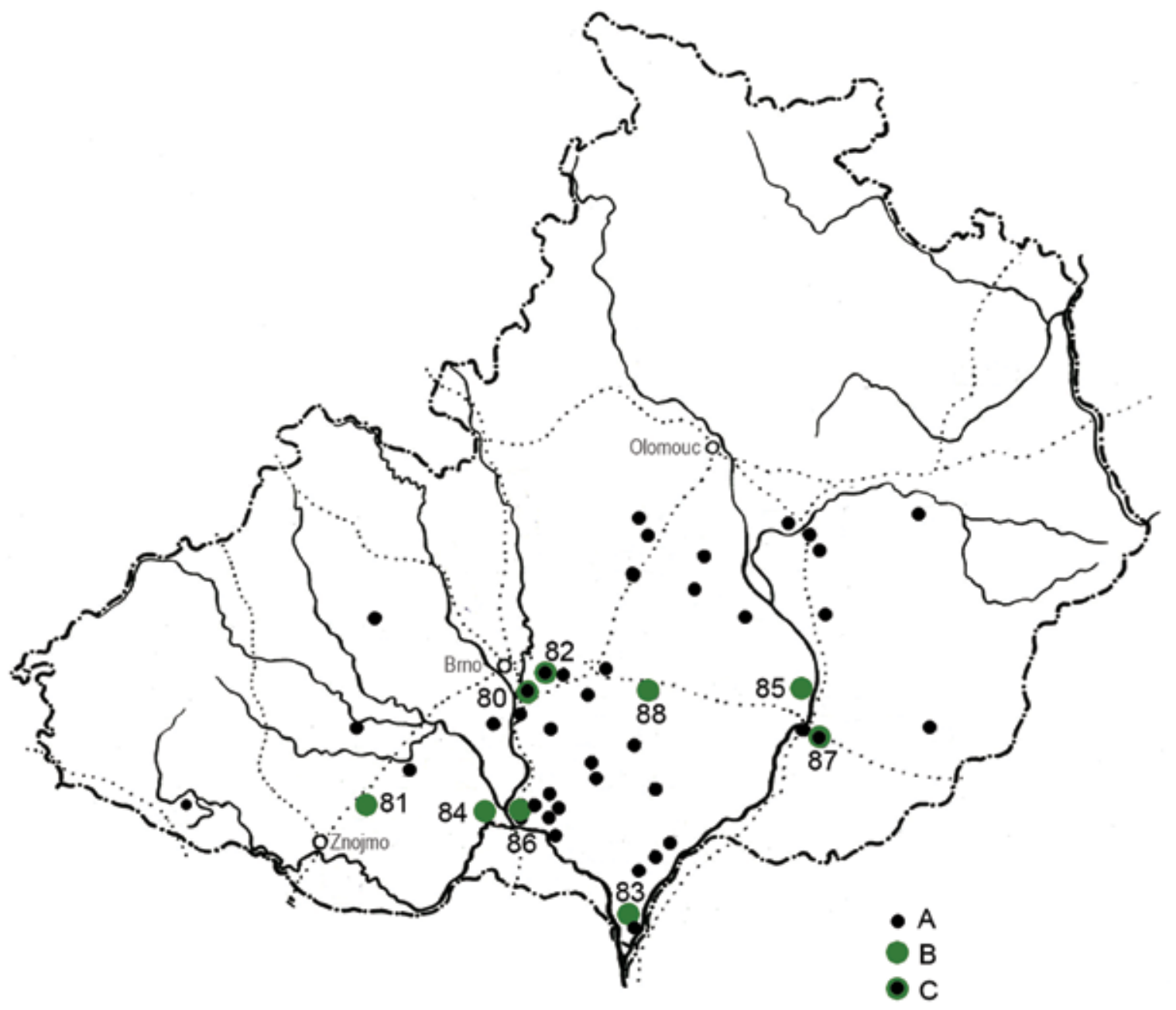

Fig. 4. Hungarian coins and fluorite beads in Moravia (partly based on ŠMERDA 1989, Obr. 1). A: Hungarian coins; B: Fluorite beads; C: Hungarian coins and fluorite beads

${ }^{40}$ Mesterházy 1993, 464-465, Figs 1 and 2.

${ }^{41}$ MRÁzeK 2000, 76.
${ }^{42}$ MRÁZEK 2000, 76 and 59-67.

${ }^{43}$ ŠMERDA 1989; VIDEMAN-MACHÁČEK 2013.

Acta Archaeologica Academiae Scientiarum Hungaricae 71, 2020 
rite beads reveals that the latter can be found along the medieval trade routes as far as Brno (four cemeteries did not contain a single Hungarian coin), while Hungarian coins can be found across the entire region (Fig. 4). In other words, the two find types have a differential distribution, similarly as in Hungary.

Twenty sites are known from Poland, ${ }^{44}$ most of which lie along the main trade routes that generally follow the rivers (Fig. 5). The Kiev-Meissen route traverses the country's southerly region in a west to east direction. Twelve of the twenty sites lie along or near this route and the overwhelming majority of the known Polish beads came to light on these settlements. The Opole site, lying in the foreland of the Moravian Gate, yielded an outstandingly high number of thirty-five fluorite beads. The route passes through Bautzen in Germany, where a girl's grave uncovered in 2015 contained ten fluorite beads.

The various glass beads from the settlements at Wrocław-Ostrów Tumski and Opole-Ostrówek were in use during roughly the same period as the beads manufactured from minerals: the trade in glass beads was most intense during the period spanning the third fourth of the eleventh century and the earlier twelfth century, corresponding to their greatest popularity as costume accessories. ${ }^{45}$

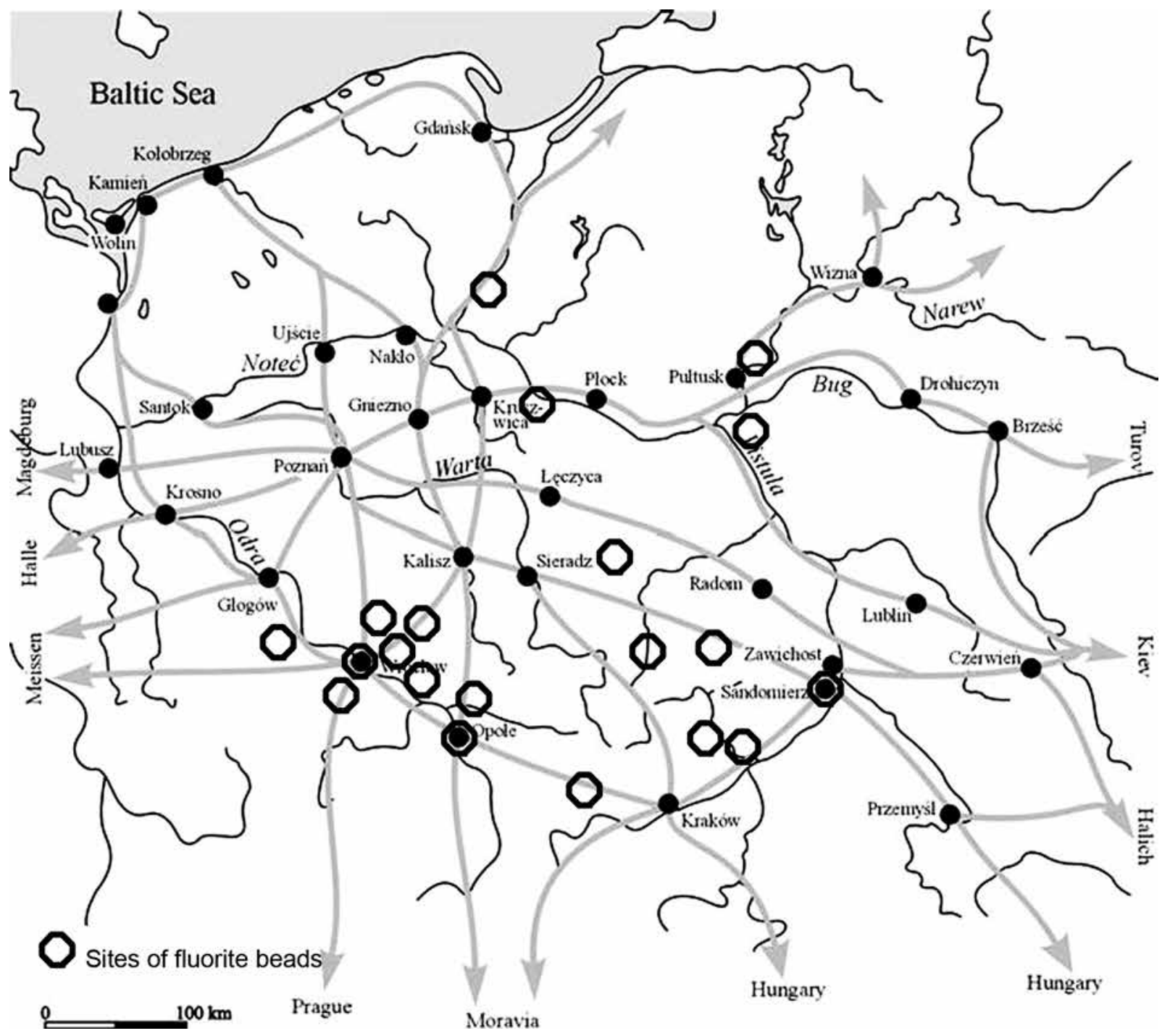

Fig. 5. Sites yielding fluorite beads in Poland and the twelfth-thirteenth-century road network (partly based on BuKo 2007, Fig. 84)

${ }^{44}$ I would like to thank Kalina Skóra for her kind help in

${ }^{45}$ PANKIEWICZ et al. 2017, 42-43. collecting the Polish sites.

Acta Archaeologica Academiae Scientiarum Hungaricae 71, 2020 
This brief overview clearly demonstrates that the number of sites yielding fluorite beads as well as the number of finds from Moravia and Poland is much lower than in the Carpathian Basin, both in terms of sites and fluorite beads.

\section{CONCLUSION}

1. The distribution of the finds and the data on the raw material suitable for the manufacture of beads clearly show that the eleventh-twelfth-century fluorite beads of the Carpathian Basin were made from fluorite originating from the Velence Hills.

2. Most studies on articles of foreign origin focused on one or another artefact type and their distribution as well as on demonstrating possible contacts between certain regions, but - with very few exceptions - failed to address the physical dimensions of, or routes whereby, these connections were established. The distribution of the fluorite beads originating from the Carpathian Basin dating from the period between the late tenth and the midtwelfth century has provided important data for the reconstruction of the medieval medium regni and of the inland trade connections and trade routes of the Carpathian Basin during the early Árpádian Age, furnishing additional support for the line of the early salt transportation routes as outlined in more recent studies. The fluorite bead distribution patterns are also an indication of the intensity of the communication between macro- and micro-regions as well as of some of their boundaries during a period for which there is a scarcity of written sources.

3. The distribution of sites and the number of finds from regions beyond the Carpathians confirms the Hungarian origins of the fluorite beads that were hitherto identified as being of "indeterminate origin". Although an export commodity of little value, these beads nevertheless played a role in foreign trade. On the testimony of the sites, the route leading to Poland through the Moravian Gate played a particularly important role in the early Árpádian Age. The well-identifiable Polish imports, including lead that was largely neglected in previous studies, arrived to the Carpathian Basin along this route during this period. ${ }^{46}$

\section{APPENDIX}

\section{SITES YIELDING FLUORITE BEADS - DATA TABLES}

A: Site; B: Cemetery/Graveyard; C: Fully/Partially explored; D: Number of beads; E: Number of graves with beads ('n': no exact data; S: stray finds); F: References or inventory number (HNM AD: Hungarian National Museum Archaeological Department)

I. Transdanubia

\begin{tabular}{|c|c|c|c|c|c|c|}
\hline & A & B & $\mathrm{C}$ & $\mathrm{D}$ & $\mathrm{E}$ & $\mathrm{F}$ \\
\hline 1 & Baracs-Apátszállás & G & $\mathrm{P}$ & $\mathrm{n}$ & $\mathrm{n}$ & KuLCSÁR 1999, 176. \\
\hline 2 & Dág & G & $\mathrm{P}$ & 62 & $5+\mathrm{S}$ & POKROVENSZKI 2015, 109-110, 113, 119, 120, 123. \\
\hline 3 & Dörgicse & G & $\mathrm{P}$ & 67 & $\mathrm{n}$ & PINTÉR 2009, 58, 60-61. \\
\hline 4 & Ellend-Nagygödör dülö & $\mathrm{C}$ & $\mathrm{F}$ & 14 & 3 & DOMBAY 1960, 140, 142, 146. \\
\hline 5 & Ellend-Szilfa dűlő & $\mathrm{C}$ & $\mathrm{F}$ & 15 & 2 & DOMBAY 1960, 153, 155. \\
\hline 6 & Fiad-Kérpuszta & $\mathrm{C}$ & $\mathrm{F}$ & 8 & 1 & SZŐKE B. 1953, 251. \\
\hline 7 & Győr-Pósdomb & $\mathrm{C}$ & $\mathrm{P}$ & 3 & 1 & MESTERHÁZY 2014, 486. \\
\hline 8 & Halimba-Cseres & $\mathrm{C}$ & $\mathrm{F}$ & 29 & 11 & TÖRÖK 1962, 104. \\
\hline 9 & Kaposvár-Apáti & G & $\mathrm{P}$ & 73 & $9+\mathrm{S}$ & $\begin{array}{l}\text { BÁRDOS 1978, 196; BÁRDOS 1987, } 23 \\
\text { (Site name: KÖLTŐ-VARGA 2019, 195.) }\end{array}$ \\
\hline 10 & Josipovo-Ciganka (HR) & $\mathrm{C}$ & $\mathrm{P}$ & 23 & $1+\mathrm{S}$ & TOMIČIĆ 1997, 17, 22. \\
\hline 11 & Kesztölc-Magasok & G & $\mathrm{P}$ & 1 & 1 & PARÁDI 1963, 69. \\
\hline 12 & Királyszentistván & G & $\mathrm{P}$ & 33 & 2 & PINTÉR 2004, 99-121. \\
\hline 13 & Középpulya/Mittelpullendorf (A) & $\mathrm{C}$ & $\mathrm{P}$ & 5 & 1 & OBENAUS 2010, 68-69. \\
\hline
\end{tabular}

${ }^{46}$ Mesterházy 1993, 466, Fig. 3. 


\begin{tabular}{|c|c|c|c|c|c|c|}
\hline & A & $\mathrm{B}$ & $\mathrm{C}$ & $\mathrm{D}$ & E & $\mathrm{F}$ \\
\hline 14 & Mesteri-Intapuszta & G & $\mathrm{P}$ & 13 & 2 & KISS G. 2000, 127; IlON 2004, No. 252. \\
\hline 15 & Palotabozsok & $\mathrm{C}$ & $\mathrm{P}$ & 5 & 3 & DOMBAY $1961,83$. \\
\hline 16 & Pécs-Vasas (=Pécs-Somogy) & $\mathrm{C}$ & $\mathrm{P}$ & 4 & 1 & DOMBAY 1961, 73. \\
\hline 17 & Polgárdi & $?$ & $?$ & 22 & $?$ & Unpublished. HNM AD Inv. no. 1884.61.1 \\
\hline 18 & Popovec-Bregi (HR) & $\mathrm{C}$ & $\mathrm{P}$ & 3 & 1 & ToMIČIĆ $1995,102$. \\
\hline 19 & Pusztaszentlászló & $\mathrm{C}$ & $\mathrm{F}$ & 128 & 16 & SZÖKE-VÁNDOR 1987, 60. \\
\hline 20 & Rábasömjén & $\mathrm{G}$ & $\mathrm{P}$ & 2 & 1 & PAPP I. K. 2012, 215. \\
\hline 21 & Sárbogárd-Tringer tanya & $\mathrm{C}$ & $\mathrm{F}$ & 3 & 1 & K. ÉRY 1968, 130. \\
\hline 22 & Sellye & $\mathrm{C}$ & $\mathrm{F}$ & 8 & 1 & Kiss A. $1968,70$. \\
\hline 23 & Sorokpolány-Berekalja & $\mathrm{C}$ & $\mathrm{F}$ & 23 & 3 & Kiss G. 2000, 173, 175. \\
\hline 24 & $\begin{array}{l}\text { Székesfehérvár-Bazilika } \\
\text { Székesfehérvár-Maroshegy }\end{array}$ & G & $\mathrm{P}$ & $\begin{array}{l}13 \\
34\end{array}$ & \begin{tabular}{|l|l|l}
1 \\
$3+S$
\end{tabular} & \begin{tabular}{|l|} 
DERCSÉNYI 1943, 20. \\
BAKAY $1968,58,59,65$.
\end{tabular} \\
\hline 25 & $\begin{array}{l}\text { Szombathely-Szent Márton- } \\
\text { templom }\end{array}$ & G & $\mathrm{P}$ & 3 & 1 & Kiss G. 2000, 245. \\
\hline 26 & $\begin{array}{l}\text { Tüskeszentgyörgy/Sveti Juraj u } \\
\text { Trnju (HR) }\end{array}$ & $\mathrm{G}$ & $\mathrm{P}$ & 30 & 3 & TOMIČIĆ 1999, 46-47; JERŠEK 29, Kat. Br. 20, 23, 26. \\
\hline 27 & Visegrád-Várkert-MNB üdülő & $\mathrm{C}$ & $\mathrm{P}$ & 7 & 2 & SZÖKE M. 1973, 119. \\
\hline 28 & Zalavár-Kápolna & $\mathrm{G}$ & $\mathrm{F}$ & 75 & 9 & $\begin{array}{l}\text { Cs. Sós 1963, 169-174. The finds from the new } \\
\text { excavations are unpublished. }\end{array}$ \\
\hline 29 & Zalavár-Monostor & $\mathrm{G}$ & $\mathrm{P}$ & 2 & 2 & Unpublished. \\
\hline 30 & Zalavár-Község & $\mathrm{C}$ & $\mathrm{F}$ & 1 & 1 & TETTAMANTI 1971, 219. \\
\hline 31 & Zágráb-Stenjevec (HR) & $\mathrm{G}$ & $\mathrm{P}$ & 2 & 1 & SIMONI 2004, Kat. 22. \\
\hline
\end{tabular}

II. North of the Danube

\begin{tabular}{|c|c|c|c|c|c|c|}
\hline & A & B & $\mathrm{C}$ & $\mathrm{D}$ & E & $\mathrm{F}$ \\
\hline 32 & Csápor/Čapor (SK) & $\mathrm{C}$ & $\mathrm{P}$ & 9 & 1 & TočIK-PAULIK 1979, 107. \\
\hline 33 & Dévény/Devín (SK) & G & $\mathrm{P}$ & 18 & 2 & PlachÁ-DivileKová 2012, 54, 62. \\
\hline 34 & \begin{tabular}{|l|}
$\begin{array}{l}\text { Ducó/Ducove-Kostelec } \\
\text { (Moravany nad Vahom) (SK) }\end{array}$ \\
\end{tabular} & G & $\mathrm{F}$ & 66 & 9 & RutTKAY, A. 1979, Catalogue No. 15, 17, 19, 20, 21, 22. \\
\hline 35 & Érsekújvár/Nové Zámky (SK) & $\mathrm{C}$ & $\mathrm{P}$ & 18 & 3 & REJHOLCOVÁ 1974, 438, 442. \\
\hline 36 & $\begin{array}{l}\text { Feketekelecsény/Čierne Klačany } \\
(\mathrm{SK})\end{array}$ & $\mathrm{C}$ & $?$ & $n$ & $\mathrm{n}$ & RUTTKAY, M. et al. 2013, 232. \\
\hline 37 & Kiskeszi/Male Kosihy (SK) & $\mathrm{C}$ & $\mathrm{F}$ & 20 & 2 & HANULIAK 1994, 45. \\
\hline 38 & Madar/Modrany (SK) & $\mathrm{G}$ & $\mathrm{P}$ & 1 & 1 & PoLla 1961, 87. \\
\hline 39 & Naszvad/Nasvad (SK) & G & $\mathrm{P}$ & 2 & 1 & NEVIZÁNSKY-PROHÁSZKa 2018, 20. \\
\hline 40 & $\begin{array}{l}\text { Nyitra-Iskola utca/Nitra-Školská } \\
\text { ulica (SK) }\end{array}$ & G? & $\mathrm{P}$ & 3 & 1 & RUTTKAY-RUTTKAYOVÁ 2018, 185. \\
\hline 41 & \begin{tabular}{|l}
$\begin{array}{l}\text { Nyitra-Šindolka/Nitra-Šindolka } \\
\text { (SK) }\end{array}$ \\
\end{tabular} & $\mathrm{C}$ & $\mathrm{F}$ & $n$ & 2 & FUSEK 1998, 107. \\
\hline 42 & $\begin{array}{l}\text { Nyitra-Molnos/Nitra-Mlynarce } \\
\text { (SK) }\end{array}$ & $\mathrm{C}$ & $\mathrm{P}$ & 1 & 1 & Tос̌IK 1960, 271. \\
\hline 43 & $\begin{array}{l}\text { Nyitrasárfö/Nitrianská Blatnica } \\
\text { (SK) }\end{array}$ & G & $\mathrm{P}$ & $n$ & $n$ & RUTTKAY, A. 1977, 246. \\
\hline 44 & Óbars/Starý Tekov (SK) & G & $\mathrm{P}$ & 14 & $1 ?$ & TočIK 1952, 36, 47, obr. 37. \\
\hline 45 & Ószéplak/Krasno (SK) & G & $\mathrm{F}$ & 11 & 5 & \begin{tabular}{|l|} 
KRUPICA 1978, 212, 221, 232, 237 \\
(GoGOVÁ 2013, 59: different data).
\end{tabular} \\
\hline 46 & \begin{tabular}{|l}
$\begin{array}{l}\text { Pozsony-Vár/Bratislava-Hrad } \\
\text { (SK) }\end{array}$ \\
\end{tabular} & G & $\mathrm{P}$ & $<4$ & 3 & POLLA-ŠTEFANOVIČOVÁ 1962, 822. \\
\hline 47 & $\begin{array}{l}\text { Turócszentmárton/Turcianský } \\
\text { Svatý Martin (SK) }\end{array}$ & G & $\mathrm{P}$ & $1 ?$ & 1 & BUDINSKY-KRIČKA 1942-1943, 38-39. \\
\hline 48 & Zobordarázs/Dražovce (SK) & $\mathrm{G}$ & $\mathrm{P}$ & 1 & & KRASKOVSKÁ 1961, 171. \\
\hline 49 & Zsitvabesenyö/Bešenov (SK) & $\mathrm{C}$ & $\mathrm{P}$ & $1 ?$ & 1 & KRASKOVSKÁ 1958, 428, 434. \\
\hline 50 & $\begin{array}{l}\text { Zsitvafödémes/Ul'an nad Žitavou } \\
\text { (SK) }\end{array}$ & $\mathrm{C}$ & $\mathrm{P}$ & 7 & 1 & LIPTÁKOVÁ 1963, 226. \\
\hline
\end{tabular}


III. Danube-Tisza interfluve

\begin{tabular}{|c|c|c|c|c|c|c|}
\hline & A & B & $\mathrm{C}$ & $\mathrm{D}$ & $\mathrm{E}$ & $\mathrm{F}$ \\
\hline 51 & Bácsfeketehegy/Feketić (SRB) & $?$ & $?$ & 10 & 1 & STANOJEV 1989, 122-123. \\
\hline 52 & Bugac-Pétermonostor & G? & $\mathrm{P}$ & 4 & $\mathrm{n}$ & Rosta 2014, Fig. 13, b \\
\hline 54 & Budapest-Árpádföld, Timúr utca & $\mathrm{G} ?$ & $\mathrm{P}$ & 27 & 2 & MELIS 1997, 58-59. \\
\hline 55 & Cegléd-Kövespart & G & $\mathrm{P}$ & 29 & $\mathrm{n}$ & $\begin{array}{l}\text { Unpublished. Kossuth Múzeum, Cegléd. Old archive } \\
\text { 17212/1926. Site: TARI 2000, } 49 .\end{array}$ \\
\hline 56 & Dánszentmiklós-Tetveshalom & G & $\mathrm{P}$ & 4 & 1 & Unpublished. Uninventoried. Kossuth Múzeum, Cegléd \\
\hline 57 & Eger-Székesegyház & G & $\mathrm{P}$ & 26 & 3 & KоZÁк 1986, 7, 9, 11. \\
\hline 58 & (Beograd) Karaburma (SRB) & $\mathrm{G}$ & $\mathrm{P}$ & $\mathrm{n}$ & $\mathrm{n}$ & BaJAlović-HaDŽI Pesić 1984, 78, Cat. No. 191. \\
\hline 59 & Mezőcsát-Csicske & G & $\mathrm{P}$ & 5 & 2 & SzABÓ 2006, 45. \\
\hline 60 & (Beograd) Mirijevo (SRB) & G & $\mathrm{P}$ & $\mathrm{n}$ & $\mathrm{n}$ & Bajalović-HaDŽI Pesić 1984, 79, Cat. No. 200. \\
\hline 61 & Piliny-Sirmány hegy & $\mathrm{C}$ & $\mathrm{P}$ & 9 & 3 & NYÁRY 1902, 219; NYÁRY 1904, 69. \\
\hline 62 & Perse/Prša (SK) & $\mathrm{C}$ & $\mathrm{P}$ & 1 & 1 & Tос̌IK 1992, 171. \\
\hline 63 & Budapest-Rákospalota, Sín utca & $\mathrm{C}$ & $\mathrm{P}$ & 28 & $2+\mathrm{S}$ & MELIS 1997, 47. \\
\hline 64 & Solt-Tételhegy & $\mathrm{G}$ & $\mathrm{P}$ & 8 & 2 & PetKes 2014, 93. \\
\hline 65 & Solt-Kalimajor & $\mathrm{C}$ & $\mathrm{P}$ & 9 & 1 & LANGÓ et al. 2015, 206. \\
\hline 66 & Szeghegy/Lovćenac (SRB) & $\mathrm{C}$ & $\mathrm{P}$ & 10 & 1 & SZÁSZ 1911, 308; STANOJEV 1989 54-56. \\
\hline 67 & Szob-Bőszob & G & $\mathrm{P}$ & 11 & $\mathrm{n}$ & $\begin{array}{l}\text { Unpublished. HNM AD 62.49.1.-11.A. Report of János } \\
\text { A. Horváth, } 1933 \text { (manuscript): HNM Central Archive } \\
\text { 10.SZ.I., 422.VII, 195.XIII.1985. }\end{array}$ \\
\hline 68 & Vajszka/Vajska (SRB) & ? & $?$ & 17 & 2 & STANOJEV 1989, 36-37. \\
\hline 69 & $\begin{array}{l}\text { Zenta-Csecstó-Paphalom/Senta } \\
\text { (SRB) }\end{array}$ & TK & $\mathrm{R}$ & 3 & 2 & STANOJEV 1989, 105-109. \\
\hline
\end{tabular}

IV. Sites along the river Tisza

\begin{tabular}{|c|c|c|c|c|c|c|}
\hline & A & B & $\mathrm{C}$ & $\mathrm{D}$ & $\mathrm{E}$ & $\mathrm{F}$ \\
\hline 70 & Hódmezővásárhely-Kápolna dűlő & $\mathrm{G}$ & $\mathrm{P}$ & 3 & $\mathrm{n}$ & SZEREMLEI 1901, 408. \\
\hline 71 & Hódmezővásárhely-Nagysziget & $\mathrm{C}$ & $\mathrm{F}$ & $\mathrm{n}$ & $\mathrm{n}$ & RÉVÉSZ 2020, 149-150. \\
\hline 72 & Karcsa-Kormoska & $\mathrm{C}$ & $\mathrm{F}$ & 25 & $5+\mathrm{S}$ & RÉVÉSZ 2011, 530, 532-535. \\
\hline 73 & Lelesz/Leles (SK) & G & $\mathrm{P}$ & $\mathrm{n}$ & $\mathrm{n}$ & $\begin{array}{l}\text { Presented by Emese Csoltkó at the Conference of Young } \\
\text { Archaeologists of the Middle Ages at Sátoraljaújhely, } \\
\text { in 2016. The excavations: ŠIMČÍK-MOLOTA } 2014 \text {. }\end{array}$ \\
\hline 74 & Sárazsadány & $\mathrm{C}$ & $\mathrm{P}$ & 7 & 1 & HoRVÁTH 2019, 111. \\
\hline 75 & Szegvár-Orom dülő & $\mathrm{C}$ & $\mathrm{F}$ & 4 & 1 & BENDE-LÖRINCZY 1997, 205, 233. \\
\hline 76 & Szomotor/Somotor (SK) & $\mathrm{C}$ & $\mathrm{P}$ & 13 & 3 & PASTOR 1955, 277-279. \\
\hline 77 & Tiszalök-Köves telek & G & $\mathrm{P}$ & 6 & 1 & Tо́тн 2014, 82. \\
\hline 78 & Tiszalúc-Sarkad & $\mathrm{C}$ & $\mathrm{F}$ & 14 & 2 & KovÁcs 2015,196. \\
\hline 79 & Tiszaörvény-Templomdomb & $\mathrm{G}$ & $\mathrm{P}$ & 5 & $\mathrm{~S}$ & Unpublished. HNM AD Inv. No. 74.48.1.-5.C. \\
\hline
\end{tabular}

V. Moravia

\begin{tabular}{|l|l|l|l|l|l|l|}
\hline & A & B & C & D & E & F \\
\hline 80 & Brněnské Ivanovice & C & P & 1 & 1 & MRÁZEK 2000, 60; Site: ŽIVNÝ 2005, 248. \\
\hline 81 & Horní Dunajovice & C & P & 5 & 1 & MRÁZEK 2000, 66; Site: ŽIVNÝ 2005, 260. \\
\hline 82 & Jiřikovice & C & P & 9 & 1 & MRÁZEK 2000, 61; Site: ŽIVNÝ 2005, 263. \\
\hline 83 & Lanžhot & C & P & n & n & MRÁZEK 2000, 66; Site: ŽIVNÝ 2005, 267. \\
\hline 84 & Mušov & C & F & 5 & 1 & MRÁZEK 2000, 64; Site: ŽIVNÝ 2005, 267. \\
\hline 85 & Nová Dědina & G? & P & 10 & 1 & MRÁZEK 2000, 67; Site: ŽIVNÝ 2005, 278. \\
\hline 86 & Strachotín-Petrova louka & G? & P & 13 & 1 & MRÁZEK 2000, 64-65; Site: ŽIVNÝ 2005, 301. \\
\hline 87 & Uherské Hradište & G & F & 11 & 4 & $\begin{array}{l}\text { MRÁZEK 2000, 66-67; GALUŠKA 2018, 265, 318, 341, } \\
\text { 345-346. }\end{array}$ \\
\hline 88 & Vicemilice & C & P & 4 & 1 & MRÁZEK 2000, 63. \\
\hline
\end{tabular}


VI. Poland

\begin{tabular}{|c|c|c|c|c|c|c|}
\hline & A & B & $\mathrm{C}$ & $\mathrm{D}$ & $\mathrm{E}$ & $\mathrm{F}$ \\
\hline 89 & Będzinie, Gora Zamkowa & $\mathrm{C}$ & $\mathrm{P}$ & 2 & 1 & RoGACZEWSKA 1998, 56. \\
\hline 90 & Brześć Kujawsk & $\mathrm{C}$ & $\mathrm{P}$ & 4 & 1 & KASZEWCY 1971, T. VII. 710. \\
\hline 91 & Dębiniec & $\mathrm{C}$ & $\mathrm{F}$ & 9 & 4 & POKUTA-WOJdA 1979, 100. \\
\hline 92 & Gorysławice & $\mathrm{C}$ & $\mathrm{P}$ & $\mathrm{n}$ & $\mathrm{n}$ & KURASIŇSKI-SKÓRA 2016, 81. Site: GLÍNSKA 2019, 272-274. \\
\hline 93 & Kałduś & $\mathrm{C}$ & $\mathrm{P}$ & 1 & 1 & ChUdZIAK-STAWSKa 2006, 62, T. 11. \\
\hline 94 & Końskie & C & $\mathrm{F}$ & 2 & 1 & GĄSsOWSKi 1950, 106-107. \\
\hline 95 & Legnica & C & $?$ & 21 & $\mathrm{n}$ & LISOWSKA 2013, 147. T. 16. \\
\hline 96 & Lubien & $\mathrm{C}$ & $\mathrm{P}$ & 6 & 1 & KURASIŃSKI-SKÓRA 2012, Fig. 30. \\
\hline 97 & Lutomiersk & $\mathrm{C}$ & $\mathrm{P}$ & 13 & 5 & NADOLSKI et al. 1959, 84. \\
\hline 98 & Maków Mazowiecki-Bazar Nowy & $\mathrm{C}$ & $\mathrm{P}$ & 2 & 1 & MARCINIAK 1960, 121. \\
\hline 99 & Masłowiec & $\mathrm{C}$ & $\mathrm{F}$ & 22 & $\mathrm{n}$ & ABRAMEK 1980, 237, 241. \\
\hline 100 & Nieporeţ & C & $?$ & 15 & $n$ & RAuHuT 1951-1952, 339. \\
\hline 101 & Opole & $*$ & $\mathrm{P}$ & 35 & $*$ & LisowSKA 2013, 147. Table 16. \\
\hline 102 & Psary & $\mathrm{C}$ & $\mathrm{P}$ & 28 & 2 & TręBAACZKIEWICZ 1963, 142. \\
\hline 103 & Radom & $\mathrm{C}$ & $\mathrm{P}$ & 4 & 1 & KURASIŇSKI-SKÓRA 2016, 79. \\
\hline 104 & Ryczyn & $\mathrm{C}$ & $\mathrm{P}$ & $n$ & $\mathrm{n}$ & KURASIŇSKI-SKÓRA 2016, 81. \\
\hline 105 & Sandomierz & $\mathrm{C}$ & $\mathrm{P}$ & 7 & 1 & GĄSSOWSKI 1969, 424. \\
\hline 106 & Tyniec Mały & $\mathrm{C}$ & $\mathrm{P}$ & 6 & $\mathrm{n}$ & LisowSKA 2013, 147. Table 16. \\
\hline 107 & Wrocław-Ostrów Tumski & $*$ & $\mathrm{P}$ & 9 & * & LisowsKa 2013, 147. Table 16. \\
\hline 108 & Złota pińczowski & $\mathrm{C}$ & $\mathrm{P}$ & 3 & 1 & GĄSSOWSKI 1953, 85. \\
\hline
\end{tabular}

*from cemetery and settlement together

\section{REFERENCES}

ABRAMEK 1980

BACH-DUŠEK 1971

BaJAlović-Hadži Pesić 1984

BAKAY 1968

BATIZI 2018

BÁRDOS 1978

BÁRDOS 1987

BENDE-LŐRINCZY 1997

BENKŐ 2015

BUDINSKY-KRIČKA 1942-1943
= B. ABRAMEK: Wczesnośredniowieczne cmentarzysko szkieletowe w Masłowicach, woj. Sieradz (An early medieval inhumation cemetery at Masłowice, province of Sieradz). SprawA 32 (1980) 227-246.

$=\mathrm{H}$. BACH-S. DuŠEK: Slawen in Thüringen. Geschichte, Kultur und Anthropologie im 10. bis 12. Jahrhundert: nach den Ausgrabungen bei Espenfeld. Weimar 1971.

= M. BAJAlović-HadžI Pesić: Nakit VIII-XVIII veka u Muzeju Grada Beograda (The Collection of Jewelry in the Belgrade City Museum). Beograd 1984.

$=\mathrm{K}$. BAKAY: Gräberfelder aus den 10. -11. Jahrhunderten in der Umgebung von Székesfehérvár und die Frage der fürstlichen Residenz (zweiter Teil) (Székesfehérvár környékének 10-11. századi temetői és a fejedelmi székhely kérdése [második rész]). Alba Regia 8-9 (1967-1968) 57-84.

= Z. BATIZI: Mining in medieval Hungary. In: The Economy of Medieval Hungary. Eds: J. Laszlovszky, B. Nagy, P. Szabó, A. Vadas. East and Central-Europe in the Middle Ages 450-1450, 49. Leiden 2018, 166-181.

= E. BÁRDOs: Középkori templom és temető Kaposvár határában. Előzetes jelentés a leletmentő ásatásról (Medieval church and cemetery on the confines of Kaposvár. Preliminary account of a rescue excavation). SMK 3 (1978) 187-234.

= E. BÁRDOs: Középkori templom és temetö Kaposvár határában: II. (Medieval church and cemetery in the vicinity of Kaposvár. Part II). SMK 8 (1987) 5-82.

= L. BENDE-G. LỏRINCZY: A szegvár-oromdülői 10-11. századi temető (Das Gräberfeld von SzegvárOromdülő aus dem 10. bis 11. Jahrhundert). MFMÉ - StudArch 3 (1997) 201-285.

$=$ E. BENKŐ: In medio regni Hungariae. In: In medio regni Hungariae. Régészeti, müvészettörténeti és történeti kutatások “az ország közepén" - Archaeological, art historical, and historical researches 'in the middle of the kingdom'. Eds: E. Benkő, K. Orosz. Budapest 2015, 11-28.

$=\mathrm{V}$. BUDINSKY-KRIČKA: Prvé nálezy staroslovanských radových pohrebišt’ na strednom Slovensku [The first finds of old Slavonic burial grounds in central Slovakia]. SbSNM 36-37 (1942-1943) 13-62. 
BUKO 2008

CHUdZIAK-STAWSKA 2006

DERCSÉNYI 1943

DOMBAY 1960

DOMBAY 1961

K. ÉRY 1968

FUSEK 1998

GALUŠKA et al. 2018

GĄSSOWSKI 1950

GĄSSOWSKI 1953

GĄSSOWSKI 1969

GEODA

GIESLER 1981

GLASER 1929

GLASER 1932

GLÍNSKA 2019

GoGOVÁ 2013

GREGOR ET AL. 2012

GYÖRFFY 1987

HANULIAK 1994

HORVÁTH 2019

HUSAR-IVANIČ 2019

ILON 2004
= A. Buko: The Archaeology of Early Medieval Poland. Discoveries-Hypotheses-Interpretations. East and Central-Europe in the Middle Ages 450-1450, 1. Leiden 2008.

= W. ChudziaK-V. Stawska: Bizuteria. In: Wczesnośredniowieczne cmentarzysko szkieletowe w Kałdusie (stanowisko 1) (Early Medieval Inhumation Cemetery at Kałdus). Ed.: W. Chudziak. Mons Sancti Lauretii 3. Toruń 2006, 62-65.

= D. DERCSÉNYI: A székesfehérvári királyi bazilika [The Royal Basilica in Székesfehérvár]. Magyarország müvészeti emlékei. 2.: Egyes emlékek és emlékcsoportok 1. Müemlékek Országos Bizottsága. Budapest 1943

= J. DomBAY: Árpád-kori temetők Baranyában I. (Friedhöfe aus der Arpadenzeit im Komitat Baranya I). JPMÉ 1960 (1961) 135-158.

= J. DOMBAY: Árpád-kori temetők Baranyában II. (Friedhöfe aus der Arpadenzeit im Komitat Baranya II). JPMÉ 1961 (1962) 80-84.

= K. K. ÉRY: Reconstruction of the tenth century population of Sárbogárd on the basis of archaeological and anthropological data - A sárbogárdi X. századi közösség rekonstrukciója régészeti és embertani adatok alapján. Alba Regia 8-9 (1967) [1968] 93-147.

$=$ G. FuSEK: Gräber mit Arpadenmünzen aus dem Gräberfeld von Šindolka in Nitra (Hroby s arpádovskými mincami z pohrebiska na Šindolke v Nitre). S1A 46 (1998) 71-118.

= L. GalušKa-V. HochmannovÁ-VÁvrovÁ-V. HrubÝ-J. MitáčeK: Uherské Hradiště-Sady. 500 let křest anství ve středí Europě. I. Katalog Pohřebiště. Hroby z 9. století až začatku 13. století [Uherské Hradište-Sady. 500 Years of Christianity in Central-Europe. I.: Catalogue of the Cemetery]. Moravské zemské muzeum, Brno 2018.

= J. GĄssowski: Cmentarzysko w Końskich na tle zagadnienia południowej granicy Mazowsza we wczesnym średniowieczu (Cemetery at Końskie from the early Middle Ages on the southern border of Mazovia). Materiały Wczesnośredniowieczne 2 (1950) 71-175.

= J. GĄssowsKi: Wczesnośredniowieczne cmentarzysko szkieletowe w Złotej pod Sandomierzem (The early medieval cemetery at Złota, Sandomierz District). WiA 19/1 (1953) 80-92.

= J. GĄssowsKi: Materiały do osadnictwa wczesnośredniowiecznego Sandomierszczyzny. (Finds of early medieval settlements from the region of Sandomierz). Materiały Wczesnośredniowieczne 6 (1969) 303-473.

$=$ Journal of the Society of the Hungarian Friends of Minerals. Budapest.

$=$ J. GIESLER: Untersuchungen zur Chronologie der Bijelo Brdo-Kultur. Ein Beitrag zur Archäologie des 10. und 11. Jahrhunderts im Karpatenbecken. PZ 56/1 (1981) 3-221.

= L. GLASER: A Dunántúl középkori úthálózata. I-II [The medieval road network of Transdanubia. I-II]. Századok 63 (1929) 138-167, 257-285.

= L. GLASER: Középkori hadiutak a Dunántúlon [Medieval military roads in Transdanubia]. HK 33 (1932) 158-164

= N. GLIŃSKA: Wiślica we wczesnym średniowieczu w świetle dotychczasowych badań archeologicznych. Stan badań i problematyka badawcza (Wiślica in the early Middle Ages in the light of the past archaeological research. Current state and research issues). https://www.academia.edu/36984646/ Wi\%C5\%9Blica_we_wczesnym_\%C5\%9Bredniowieczu_w_\%C5\%9Bwietle_dotychczasowych_ bada\%C5\%84_archeologicznych._Stan_bada\%C5\%84_i_problematyka_badawcza?email_work_ card = title. Visited: 18.02 .2020

= S. GogovÁ: Kostolný cintorín v Krásne: Tribečské spoločenstvo vo vrcholnom stredoveku (Church Cemetery in Krásno. Tribeč Communitiy in the High Middle Ages). Hradec Králové 2013.

= M. GREGOR-L'. VANČO-M. KADLEČIKOVÁ: Mineralogické štúdium korálikov z cintorína z 11.-12. storočia z hardu Devín (Mineralogische Untersuchung der Perlen vom Friedhof aus dem 11.-12. Jahrhundert der Burg Devín). SlA 60 (2012) 157-168.

= GY. GYÖRFFY: Az Árpád-kori Magyarország történeti földrajza - Geographia historica Hungariae tempore stirpis Arpadienne. II.: D-Gy. Doboka, Erdélyi Fejér, Esztergom, Fejér, Fogaras, Gömör és Győr megye. Budapest 1987.

= M. HanuliaK: Malé Kosihy I. Pohrebisko z 10.-11. storočia (archeologickohistorické vyhodnotenie) (Malé Kosihy I. Gräberfeld aus dem 10.-11. Jh. in Malé Kosihy). Nitra 1994.

= C. HorvÁTH: Régészeti tanulmányok a Bodrogköz 10-11. századi településtörténetéhez [Archaeological Studies of the 10-11 $1^{\text {th }}$ Century Settlement History of the Bodrogköz]. Budapest 2019.

= P. HusaR-M. Ivanič: Prechody cez dolný a stredný tok rieky Váh vo vrcholnom a neskorom stredoveku v kontexte písomných a hmotných prameňov (Crossings over the lower and central reaches of the River Váh in the high and late Middle Ages in the context of written and material sources = Flussübergänge am Unter- und Mittellauf der Waag im Hoch- und Spätmittelalter im Kontext von schriftlichen und materiellen Quellen). AH 44/2 (2019) 1029-1055.

= G. ILON: Mesteri-Intaháza. Ásatási jelentés [Mesteri-Intaháza. Excavation report]. In: Régészeti kutatások Magyarországon 2003. Ed.: J. Kisfaludi. Budapest 2004, 251. 
JERŠEK 2018

KASZEWSCY 1971

KÁKAY SZABÓ 1974

KISs A. 1967

KISS G. 2000

KovÁcs 2015

KovÁcs 2019

KoZÁK 1986

KÖLTŐ-VARGA 2019

KRASKOVSKÁ 1958

KRASKOVSKÁ 1961

KRUPICA 1978

KUBINYI 1994

KULCSÁR 1999

KURASIŃSKI-SKÓRA 2012

LANGÓ et al. 2015

LIPTÁKOVÁ 1963

LISOWSKA 2013

MARCINIAK 1960

MELIS 1997

MESTERHÁZY 1993

Mesterházy 2014

Minerals 2002

MRÁZEK 2000
= P. JERŠEK: Groblja 10. i 11. stoljeća u Međimurju. Diplomski rad [10-11 ${ }^{\text {th }}$ Century Cemeteries in Međimurje]. Sveučilište u Zagrebu Filozofski Fakultet Odsjek za arheologiju. Zagreb 2018: http:// darhiv.ffzg.unizg.hr/id/eprint/10860/. Visited: 17. 03. 2019.

= E. KASZEWSKA-Z. KASZEWSKI: Wczesnośredniowieczne cmentarzysko w Brześciu Kujawskim, pow. Włocłavek (The early medieval cemetery at Brześc Kujawski, Włocławek District). MatWroc 1 (1971) 365-434.

= O. KÁKAY SZABÓ: A székesfehérvári sírleletek fluorit-nyaklánca [Fluorite necklace among the grave finds from Székesfehérvár]. MÁFIJ 1974 (1976) 339-342.

= A. KISS: A sellyei Árpád-kori temető (Das Gräberfeld aus der Arpadenzeit in Sellye). JPMÉ 1967 (1968) 69-74.

= G. KISs: Vas megye 10-12. századi sír- és kincsleletei (Angaben zur Geschichte des Komitats Vas im 10.-12. Jahrhundert). Magyarország honfoglalás kori és kora Árpád-kori sírleletei 2. Szombathely 2000.

= L. KovÁCs: A tiszalúc-sarkadi 11. századi temető (10th-11th-century graves and stray finds of the Taktaköz Region and the $11^{\text {th }}$-century cemetery of Tiszalúc-Sarkad). In: Kovács László: A Taktaköz 10-11. századi sír- és szórványleletei, valamint a tiszalúc-sarkadi 11. századi temető. Magyarország honfoglalás kori és kora Árpád-kori sírleletei 9. Szeged 2015, 91-220

= L. KovÁcs: Magyarhomorog-Kónya-domb 10. századi szállási és 11-12. századi falusi temetője (A $10^{\text {th }}$-Century Cemetery Belonging to a Short-Lives Settlement and a $11^{\text {th }}-12^{\text {th }}$ Century Village Cemetery, Both Located on Magyarhomorog-Kónya-Domb). Magyarország honfoglalás kori és kora Árpád-kori sírleletei 12. Szeged-Budapest 2019.

= K. KoZÁK: Az egri vár Árpád-kori temetőjének feltárása III. (Freilegung des arpadenzeitliches Friedhofes in der Burg von Eger III). Agria 22 (1986) 3-34.

= L. KÖLTŐ-M. VARGA: Kaposvár és környéke az avar korban és a kora Árpád-korban (Kaposvár (Hungary) and its surroundings in the Avar-Age and in the Early Árpádian-Period). Hadtudományi Szemle Spec.No. 12 (2019) 147-200.

= L. KRASKOvSKÁ: Výskum v Bešeňove r. 1950 (Ausgrabung in Bešeňov im J. 1950). SlA 6 (1958) 419-447.

= L. KRASKOVSKÁ: Výskum na hradisku v Dražovciach (Forschungsgrabung am Burgwall in Dražovce). ŠtZ 6 (1961) 161-184.

= O. KRUPICA: Stredoveké Krásno (Das mittelalterliche Krasno). Zapadné Slovensko 5 (1978) 169-333.

= A. KubinYi: Só [Salt]. In: Korai magyar történeti lexikon [Lexicon of the Early Hungarian History]. Ed.: Gy. Kristó. Budapest 1994, 603.

= M. Kulcsár: Baracs-Apátszállás (ásatási jelentés) 1999 [Baracs-Apátszállás. Excavation report]. Alba Regia 29 (1998-1999) [2000] 176

$=$ T. KURASIŃSKI-K. SKÓRA: Wczesnośredniowieczne cmentarzysysko szkieletowe w Lubienu pow. Piotrkowski (Early Medieval Cemetery in Lubien, Piotrkowski District). Łódz 2012.

= P. LAngó-Zs. PetKes-R. Soós: Beszámoló a Solt-Kalimajor lelőhelyen folytatott kutatásról (Account about the research in the discovery place in Solt-Kalimajor). In: ,... in nostra lingua Hring nominant”. Tanulmányok a 60 éves Szentpéteri József születésnapja tiszteletére. Eds: Cs. Balogh, Zs. Petkes, B. Sudár, Zs. Zsidai. Budapest 2015, 201-219.

= Z. LIPTÁKOVÁ: Slovanské pohrebiško u X.-XI. stroročia v Ul'anoch nad Žitavou [10-11 ${ }^{\text {th }}$ Slavonic cemetery at Ulan nad Žitavou]. SlA 11 (1963) 225-236.

= E. LISOwSKA: Wydobycie i dystrybucja surowców kamiennych we wczesnym średniowieczu na Dolnym Śląsku (Production and Distribution of Stone Raw Materials in the Early Middle Ages in Lower Silesia). Wrocław 2013.

= J. MARciniaK: Wczesnośredniowieczny zespoł osadniczy w miejscowości Bazar Nowy pow. Makow Mazowiecki (Early medieval settlement complex in Bazar Nowy, Makow Mazowiecki District) Materiały Wczesnośredniowieczne 5 (1960) 99-140.

= K. I. Melis: Árpád-kori temetők Pest határában (Cimetières de l'époque Árpádienne [11-13 $3^{\mathrm{e}}$ siècles] sur la périphére de Pest). BudRég 31 (1997) 41-78.

= K. MESTERHÁZY: Régészeti adatok Magyarország 10-11. századi kereskedelméhez [Archaeological data for the $10^{\text {th }}-11^{\text {th }}$ century trade of Hungary]. Századok 127 (1993) 450-468.

$=\mathrm{K}$. Mesterházy: A Györ-pósdombi 10-11. századi temetö (The $10^{\text {th }}-11^{\text {th }}$ century cemetery of GyőrPósdomb). In: C. Horváth: Győr és Moson megyék honfoglalás és kora Árpád-kori temetői és sírleletei. Magyarország honfoglalás kori és kora Árpád-kori sírleletei 8. Szeged 2014, 457-509.

$=$ GH. Udubasa-R. ĎuĎA-S. SzaKÁll-V. Kvasnytsya-E. KoszowsKa-M. NovÁK: Minerals of the Carpathians. Ed.: S. Szakáll. Praha 2002.

= I. MRÁzEK: Drahé kameny ve středověku Moravy a Slezska (Edelsteine im Mittelalter Mährens und Schlesiens). Brno 2000. 
NADOLSKI et al. 1959

NEVIZÁNSKY-PROHÁSZKA 2018

NYÁRY 1902

NYÁRY 1904

OBEnAus 2010

PANKIEWICZ et al. 2017

PAPP G. 2018

PAPP I. K. 2012

PARÁDI 1963

PASTOR 1955

PetKes 2014

PINTÉR 2004

PINTÉR 2009

Plachá-Divileková 2012

POKROVENSZKI 2015

POKUTA-WOJDA 1979

Polla 1961

Polla-ŠTEFANOVIČOVÁ 1962

PósTa 1906

RAUHUT 1951-1952

REJHOLCOVÁ 1974

RÉVÉSZ 2011

RÉVÉSZ 2020

RoGACZEWSKA 1998
= A. NADOLSKI-A. ABRAMOVICZ-T. PoKLEWSKI: Cmentarzysko z XI wieku w Lutomiersku pod Łodzią (11th century cemetery in Lutomiersku near Lodz). Acta archaeologica Universitatis Lodziensis 7. Łódzkie Towarzystwo Naukowe, Wydział II: Nauk historycznych i społecznych 25. Łódź 1959.

= G. NEVIZÁNSKY-P. PROHÁsZKA: Stredoveký a včasnonovoveký kostolný cintorín v Nesvadoch. Výskum Bélu Szőkeho v rokoch 1938 a 1943. (Der mittelalterliche und frühneuzeitliche Kirchenfriedhof in Nesvady-Jánoskapart. Die archäologische Forschungen von Béla Szőke in den Jahren 1938 und 1943). Nitra 2018.

= A. NYÁRY: Temető királyságunk első századából [Cemetery from the first century of Hungarian Kingdom]. ArchÉrt 22 (1902) 238-245.

= A. NYÁRY: A pilinyi Árpád-kori temető [Árpádian Age cemetery at Piliny]. ArchÉrt 24 (1904) 86-106.

= M. OBEnAUs: Arpadenzeitliche Gräberfelder und Grabfunde des 10. bis 12. Jahrhunderts in Ostösterreich - Fundmaterialien des Burgenländischen und Niederösterreichischen Landesmuseums. Wissenschaftliche Arbeiten aus dem Burgenland 135. Eisenstadt 2010.

= A. PAnkiewicz-S. Siemianowska-K. SAdowski: Wczesnośredniowieczna biżuteria szklana z głównych ośrodków grodowych Śląska (Wrocław, Opole, Niemcza) (Early Mediaeval Glassjewellery from Main Silesian Stronghold Complexes - Wrocław, Opole, Niemcza). In pago Silensi. Wrocławskie studia wczesnośredniowieczne 3. Wrocław 2017.

= G. PAPP: Büvös kockák a föld alól [Magic cubes from underground]. ÉlTud 2018/49, 1556-1559.

= I. K. PAPP: Államalapítás kori temető Rábasömjén temploma mellett. Régészeti adatok Vas megye templom körüli temetőinek kialakulásához (Der Friedhof an der Kirche von Rábasömjén aus der Staatsgründungszeit. Archäologische Angaben zur Entstehung der Kirchfriedhöfe im Komitat Vas). Savaria 35 (2012) 211-250.

= N. PARÁDI: Kesztölc-Magasok. Ásatási jelentés [Kesztölc-Magasok. Excavation report]. RégFüz I/16 (1963) 69.

= J. PASTOR: Belobrdské pohrebište v Somotore [Cemetery of the Bijelo Brdo culture in Somotor]. S1A 3 (1955) 276-285.

= Zs. PETKES: Árpád-kori temető a tételhegyi Templom-dombon (An Árpádian Age cemetery in the Templomdomb area of the Tételhegy site). Archaeologia Cumanica 3 (2014) 85-110.

= L. PINTÉR: Királyszentistván templom körüli temetője (The cemetery surrounding Királyszentistván church). VMMK 23 (2004) 99-121.

= L. PINTÉR: Dörgicse-Felsődörgicse, Szt. Péter-templomrom melletti kora Árpád-kori és késő középkori temetőrészlet (Arpadian Age and late medieval cemetery of the St. Peter-Church at DörgicseFelsődörgicse). In: Veszprém megye egyházi élete a középkorban. Kiállítási katalógus. 2008-2009 - Ecclesiastical Life in Veszprém County in the Middle Ages. Exhibition catalogue. 2008-2009. Ed.: P. Rainer. Veszprém 2009, 56-63.

= V. Plachá-D. DivileKovÁ: Cintorín z 11-12. storočia na hrade Devín (Friedhof aus dem 11.-12. Jahrhundert aus der Burg Devín). SlA 60 (2012) 45-118.

= K. PoKrovenszKI: Árpád-kori temetőrészlet Dégről (Arpadenzeitliche Bestattungen von Dég). Alba Regia 43 (2015) 105-115.

= Z. PoKUTA-L. WojdA: Wczesnośredniowieczne cmentarzysysko we wsi Dębina, woj. sieradzkie (Cemetery from the early Middle Ages in Dębiniec). PMMAE 26 (1979) 89-141.

= B. Polla: Včasnostredoveké pohrebisko v Modranoch, okr. Komarno [Early medieval cemetery at Modran, Komarno county]. SbČSSA 1 (1961) 87-92.

= B. Polla-T. ŠTeFAnOviČovÁ: Slovanské pohrebisko na Bratislavskom hrade [Slavic cemetery at Bratislava Castle]. AR 14 (1962) 814-823.

= B. PóstA: Régészeti tanulmányok Oroszföldön. II.: Zichy Jenő gróf harmadik ázsiai utazása. IV. Archäologische Studien auf russischem Boden. II.: Dritte asiatische Forschungsreise des Grafen Eugen Zichy. IV. Budapest-Leipzig 1906.

= L. RAUHUT: Wczesnośredniowieczne cmentarzysko szkieletowe z przełomu XI-XII w. w Nieporęcie (The early Middle Ages cemetery at Nieporęc). WiA 18 (1951-1952) 323-344.

= M. REJHOLCOvÁ: Pohrebisko z 10. - 12. storočia v Nových Zamkoch (Gräberfeld aus dem 10.-12. Jahrhundert in Nové Zámky). S1A 22 (1974) 433-460.

= L. RÉVÉSz: 11. századi temető Karcsa-Kormoskán (Gräberfeld des 11. Jahrhunderts von KarcsaKormoska). MFMÉ - StudArch 12 (2011) 529-558.

= L. RÉVÉSZ: A 10-11. századi temetők regionális jellemzői a Keleti-Kárpátoktól a Dunáig (Regional features of the $10-11^{\text {th }}$ century cemeteries from the eastern Carpathians to the Danube). Magyarország honfoglalás kori és kora Árpád-kori sírleletei 13. Szeged-Budapest 2020.

= A. Rogaczewska: Cmentarzysko wczesnośredniowieczne na Górze Zamkowej w Będzinie. Stanowisko 2 (Early medieval cemetery on the Castle Hill in Będzin, site number 2). Zeszyty Zagłębiowskie 4 (1998) 41-116. 
F. ROMHÁNYI 2018

RUTTKAY, A. 1977

RUTTKAY, A. 1979

RuTTKAY, A. 1996

RUTTKAY, M. et al. 2013

RUTTKAY-RUTTKAYOVÁ 2018

SIMONI 2004

Cs. Sós 1963

STANOJEV 1989

ŠIMČÍK-MOLOTA 2014

ŠMERDA 1989

SZABÓ 2006

SZEREMLEI 1901

SZILÁGYI K. 1994

SZILÁGYI K. 1995

SZILÁGYI M. 2012

SzŐKE B. et al. 1953

SZŐKE M. 1973

SZŐKE-VÁNDOR 1987

SZTRÓKAY 1978

SZÜCS 2002

TARI 2000

TetTamanti 1971

TOČIK 1952

TOČIK 1960

TOČIK 1992

TočÍK-PAULIK 1979
= B. F. RomHÁNYI: Salt mining and trade in Hungary before the Mongol Invasion. In: The Economy of Medieval Hungary. Eds: J. Laszlovszky, B. Nagy, P. Szabó, A. Vadas. East and Central-Europe in the Middle Ages 450-1450, 49. Leiden 2018, 182-204.

= A. T. RUTTKAY: Výskum zaniknutého včasnostredoveko sidliska, architektúry a pohrebiska pri Nitrianskej Blatnici (Erforschung für mittelalterlicher Siedlung, Architektur und Gräberfeld bei Nitrianska Blatnica im Jahre 1976). AVANS 1976 (1977) 243-250.

= A. T. RutTKaY: Stredoveké umelecké remeslo (Arts décoratifs de Moyen Age). Bratislava 1979.

= A. T. RuttKaY: Mittelalterlicher Friedhof in Ducové, Flur Kostolec, Bez. Trnava: Beitrag zum Studium der Beziehungen zwischen den sog. Reihengräberfeldern und Kirchenfriedhöfen vor dem 13. Jahrhundert. In: Ethnische und kulturelle Verhältnisse an der mittleren Donau vom 6. bis zum 11. Jahrhundert. Hrsg.: D. Bialeková, J. Zabojnik. Bratislava 1996, 391-409.

= M. RutTKAY-K. DaŇOvÁ-M. CHeBEN-Z. PolÁKovÁ-B. ZAJACOvÁ: Záchranné archeologické výskumy na trase výstavby rýchlostnej cesty R1 v úseku Beladice-Tekovské Nemce (Archäologische Rettungsgrabungen beim Bau der Schnellstraße R1 im Abschnitt Beladice-Tekovské Nemce). AVANS 2009 (2013) 229-236.

= M. RUTTKAY-J. RUTTKAYOVÁ: Výskum stredovekého osídlenia a pohrebiska v Nitre na Školskej ulici (Research of the medieval settlement and cemetery at Školska Street in Nitra). ŠtZ 64 (2018) 169-200.

= K. Simoni: Stenjevec - Starohrvatsko groblje (Stenjevec - Old Croatian Cemetery). Zagreb 2004.

= A. Cs. Sós: Die Ausgrabungen Géza Fehérs in Zalavár. ArchHung 41. Budapest 1963.

= N. STANOJEV: Nekropole X-XV veka u Voivodini (Nekropolen aus dem 11.-15. Jahrhundert in der Vojvodina). Arheloško društvo Vojvodine, Katalog 1. Novi Sad 1989.

= P. ŠIMČÍK-T. MoLOTA: Kláštor premonštrátov v obci Leles - archeologický výskum v roku 2014 (Monastery of Premonstrates in Leles. Excavation report]. Slovenská archeologická spoločnost'. Informátor (Nitra) 25/2 (2014) 23.

= J. ŠMERDA: Nálezy uherskych minci na Moravě z 11. a 12. století (Funde ungarischen Münzen in Mähren aus dem 11. und 12. Jahrhundert). SlovNum 10 (1989) 223-234.

= L. SzABÓ: Árpád-kori templom és temetö Mezőcsát határában (An Arpadian Age church and cemetery on the outskirts of Mezőcsát). HOMÉ 45 (2006) 25-90.

= S. SzEREMLEI: Hód-mező-Vásárhely története. II. : Az ököljog kora. I. Istvántól a Mohácsi vészig [The History of Hód-mező-Vásárhely. II.: The Age of Fist Law. From Stephen I. to the Mohács Disaster]. Hódmezővásárhely 1901.

= K. SZILÁGYI: Perlentypen aus dem X.-XII. Jahrhundert in Ungarn und ihre archäologische Bedeutung. PA 85 (1994) 75-110.

$=$ K. SZILÁGYI: The beads of tenth- to twelfth-century Hungary. BEADS: Journal of Society of Bead Researchers 7 (1995) 65-97.

= M. SzILÁGYI: Arpad-Period Communication Networks: Road Systems in Western Transdanubia. [PhD Dissertation in Medieval Studies. CEU, Manuscript.] Budapest 2012.

= B. SzŐKE-J. NemeskérI-P. LiptáK: Le cimetière du XI ${ }^{\mathrm{e}}$ siècle de Kérpuszta. ActaArchHung 3 (1953) 205-279.

= M. SzŐKE: Visegrád-Várkert, Nemzeti Bank üdülö. Ásatási jelentés [Visegrád-Várkert, Nemzeti Bank üdülő. Excavation report]. RégFüz I/26 (1973) 119.

= B. M. SzŐKE-L. VÁNDOR-I. KISZELY: Pusztaszentlászló Árpád-kori temetője (Arpadenzeitliches Gräberfeld aus Pusztaszentlászló). FontArchHung. Budapest 1987.

= K. SzTRÓKAY: Dr. Erdélyi János emlékezete [In memoriam of János Erdélyi]. http://epa.oszk.hu > pdf > EPA02934_mafi_evi_jel_1978_029-038. Visited: 18. 09. 2019.

= J. SzŰCS: Az utolsó Árpádok [The Last Kings of the Árpád Dinasty]. Budapest 2002.

$=$ E. TARI: Pest megye középkori templomai (Medieval Churches of Pest County). StComit 27. Szentendre 2000.

= S. TeTtAmanti: A Zalavár-községi I. számú XI. századi temető (Das Gräberfeld Nr. I. von ZalavárKözség [11.Jh.]).) ArchÉrt 98 (1971) 216-244.

= A. TočIK: Zist'ovacie výskumy v St. Tekove na Slovensku [Surveys at St. Tekov, Slovakia]. AR 4 (1952) 35-37.

= A. TočIK: Radové pohrebisko devínskeho typu z XI. stor. v Mlynárciach pri Nitre $\left[11^{\text {th }}\right.$ century row cemetery of Devin type from the at Mlynárce near Nitra]. S1A 8 (1960) 269-284.

= A. TočIK: Materiály k dejinám južného Slovenska v 7.-14. storoči (Materialien zur Geschichte der Südslowakei im 7.-14. Jahrhundert). ŠtZ 28 (1992) 3-250.

= A. TočIK-J. PAULIK: Mohyla z mladšej doby bronzovej a kostrové pohrebisko z 11. storočia v Čapore (Ein Hügelgrab aus der jüngeren Bronzezeit und ein Gräberfeld aus dem 11. Jahrhundert in Č́́por). S1A 27 (1979) 87-120. 
TOMIČIĆ 1995

TOMIČIĆ 1997

TOMIČIĆ 1999

TóTH 2014

TÖRÖK 1954

TÖRÖK 1962

TRĘBACZKIEWICZ 1963

VIDEMAN-MACHÁČEK 2013

ŽIVNÝ 2005
= Ž. TomičIĆ: Na tragu bjelobrdske kulture u kalničkom prigorju (Bijelo Brdo culture in the Kalnik hills). SHP 3 (1995) 99-122.

= Ž. Tomičıć: Zvonimirovo i Josipovo: groblja starohrvatskog doba u Virovitičko-podravskoj županiji = Zvonimirovo and Josipovo : Graveyards from the Croatian Early Mediaeval Period in the Virovitica and Podravina Country. Zagreb 1997.

= Ž. ToмIČIĆ: Ranosrednjovjekovno groblje u Sv. Jurju u Trnju u Međimurju. Prinos datiranju nalazišta (Der frühmittelalterliche Friedhof in Sv. Juraj u Trnju in Međimurje - Ein Beitrag zur Datierung der Fundstelle). Prilozi Instituta za arheologiju u Zagrebu 15-16 (1998-1999) 41-61.

= A. Tóтн: A nyíri Mezőség a 10-11. században (10-11 ${ }^{\text {th }}$ Century Cemeteries of Nyír-Mezőség). Magyarország honfoglalás kori és kora Árpád-kori sírleletei 7. Szeged 2014.

$=$ GY. TöRÖK: Halimba-Cseres X-XII. századi temetője [The $10^{\text {th }}-12^{\text {th }}$ century cemetery of HalimbaCseres]. FolArch 6 (1954) 95-105.

= Gy. TöröK: Die Bewohner von Halimba im 10. und 11. Jahrhundert. ArchHung 39. Budapest 1962.

= T. TręBACZKIEwiCz: Cmentarzysko wczesnośredniowieczne w wsi Psary, pow. Piotrków Trybunalski (Early medieval cemetery in the village of Psary, Piotrków Tybunalski county). PMMAE 9 (1963) 131-166.

= J. ViDEMAN-J. MACHÁČEK: Nové mincovní nálezy z dolního Podyjí v kontextu raně středověké Moravy (New coin finds from the lower Dyje (Thaya) River region in the context of early medieval Moravia). AR 45 (2013) 851-871.

= M. ŽIVNÝ: Pohrební ritus na Morave v 11. -15. století ve středoevropském kontextu (The Burial Rite in Moravia in $11^{\text {th }}-15^{\text {th }}$ Century in Context of Central Europe). https://www.academia. edu/14343097/Poh\%C5\%99ebn\%C3\%AD_ritus_na_Morav\%C4\%9B_v_11._-_15._ stolet\%C3\%AD_ve_st\%C5\%99edoevropsk\%C3\%A9m_kontextu. Visited: 24. 07. 2016

Open Access. This is an open-access article distributed under the terms of the Creative Commons Attribution 4.0 International License (https:// creativecommons.org/licenses/by/4.0), which permits unrestricted use, distribution, and reproduction in any medium, provided the original author and source are credited, a link to the CC License is provided, and changes - if any - are indicated. (SID_1) 
